This item was submitted to Loughborough's Research Repository by the author.

Items in Figshare are protected by copyright, with all rights reserved, unless otherwise indicated.

\title{
Enhancing commitment through work empowerment
}

PLEASE CITE THE PUBLISHED VERSION

http://dx.doi.org/10.1108/09699980710829021

PUBLISHER

(c) Emerald Group Publishing Limited

VERSION

AM (Accepted Manuscript)

LICENCE

CC BY-NC-ND 4.0

REPOSITORY RECORD

Liu, Anita, W.M. Chiu, and Richard Fellows. 2019. "Enhancing Commitment Through Work Empowerment". figshare. https://hdl.handle.net/2134/11055. 
This item was submitted to Loughborough's Institutional Repository (https://dspace.lboro.ac.uk/) by the author and is made available under the following Creative Commons Licence conditions.

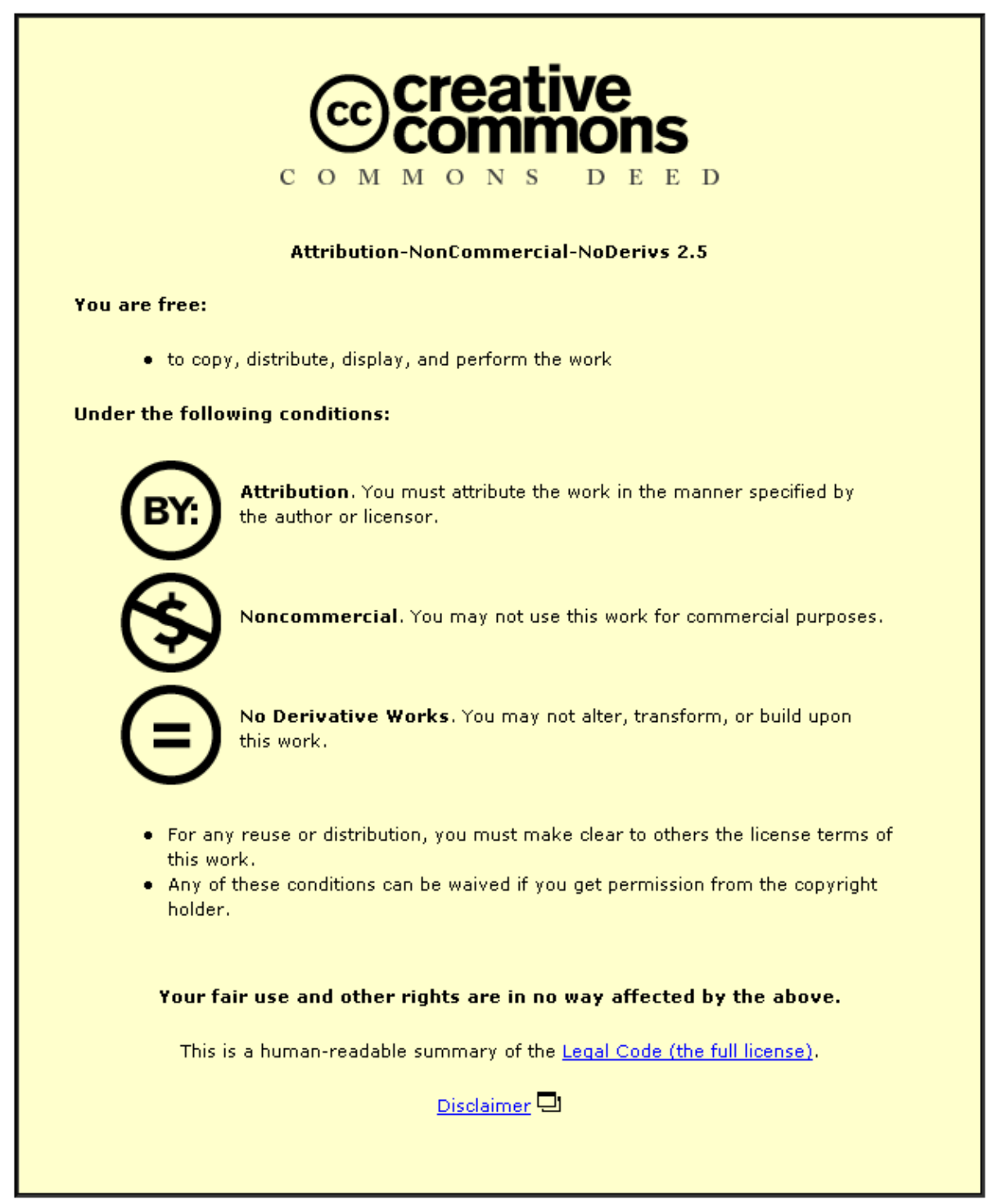

For the full text of this licence, please go to: http://creativecommons.org/licenses/by-nc-nd/2.5/ 


\title{
Enhancing Commitment through Work Empowerment
}

\author{
Anita M M Liu ${ }^{1}$, W.M. Chiu ${ }^{1}$, Richard Fellows ${ }^{2}$ \\ ${ }^{1}$ Department of Real Estate and Construction, The University of Hong Kong. \\ ${ }^{2}$ School of the Built and Natural Environment, Glasgow Caledonian University, UK; and \\ Department of Real Estate and Construction, The University of Hong Kong.
}

\section{Acknowledgement}

This paper is supported by HKU CRCG research grant.

\section{Corresponding author:}

Dr. Anita M M Liu, Dept. of Real Estate and Construction, University of Hong Kong,

Pokfulam, Hong Kong.

Tel: +85225492319

Fax: +85225599457

Email: ammliu@hkucc.hku.hk

\begin{abstract}
Purpose of the paper: The rationale of the belief that empowerment of members of the workforce is a universal desirable relates to problems of 'command and control' within organisations as well as the expectation that empowerment leads to greater commitment by employees and, thereby, results in enhanced performance. The research objectives are to investigate the perception of work empowerment of quantity surveyors and if perceived work empowerment is an antecedent of commitment.
\end{abstract}

Design/methodology/approach: An exploratory study amongst quantity surveyors in four different types of construction industry organisations in Hong Kong is conducted. Data are collected by use of established questionnaires, yielding 136 valid responses.

Findings: Organisational commitment comprises dimensions of affectiveness and continuance. It is found that when the perception of work empowerment increases, organisational commitment increases accordingly. Work empowerment is related to affective commitment rather than continuance commitment. Professional qualification and nationality are positively correlated with both dimensions of organisational commitment. Chinese chartered quantity surveyors show more commitment to their organisations. Generally, male QS shows less continuance commitment and the longer the QS has worked for the organisation (particularly in consultancy firms), the less continuance commitment one has. Original/Value of the paper: The regression analysis supports the relationship of commitment and work empowerment. Work empowerment enhances self efficacy and, through motivation and commitment, leads to increased performance and effectiveness.

Keywords: empowerment; organisational commitment; quantity surveyors 


\section{Introduction}

In this era of rapid change, organisations keep readjusting/adapting to the environment in order to maintain their effectiveness and competitiveness. It is believed that motivating and empowering employees can enhance their productivity and performance (e.g., Schein, 1980; Vroom 1964). Individuals who are motivated would be more committed to their tasks and, hence, perform better. Committed individuals are also less likely to leave their organisations.

Effort to induce commitment can produce long-term benefits for the organisation. Sarantinos (2007) alleges that commitment is directly tied to the psychological contract, which, in essence, describes the implicit agreement between employees and the organisation with regards to their reciprocal obligations and perceived expectations. Group goals and goal commitment predict group producitivity and job satisfaction (Antoni 2005). Participative group management (Likert 1961) is believed to achieve higher productivity, greater involvement of employees and so, better relations in an organisation as managers focus on the needs and expectations of subordinates to establish and maintain effective work groups.

Vroom's $(1964,1995)$ 'expectancy theory' recognises the forces within individuals in the environment which affect an individual's behaviour. It assumes that the employee can decide how much effort he puts in, depending on his motivation, which equals the product of valence (attractiveness of a reward), expectancy (how much a person believes that their effort will result in success) and instrumentality (belief that success will lead to reward). Schein (1980) believes the most important factor in determining an individual's motivation is the psychological contract, defined as the set of expectations between an employee and some implicit components of an organisation, i.e. pay, dignity, opportunities. In return, the organisation demands loyalty and commitment. Schein's research illustrates the importance of human resource planning. Work empowerment is a resultant concept developed from these theories.

An empowered environment is of particular importance to achieve work effectiveness and influences the values held by a person towards an organisation. The motivational aspect of empowerment (Liu and Fang, 2006) and the effects of individuals' commitment on performance in construction projects are investigated by Liu and Walker (1998), Dainty, Bryman, Price, Greasley, Soetanto and King (2005), Leung, Chong, Ng and Cheung (2004) and Peansupap and Walker (2006). This study focuses on the individuals' perceptions (quantity surveyors in this sample of study) of the extent of work empowerment and their organisational commitment. The research objectives are to investigate:

1) the perception of work empowerment of quantity surveyors;

2) if perceived work empowerment is an antecedent of commitment by quantity surveyors

\section{Work Empowerment and Commitment}

Conger and Kanungo (1988) examine work empowerment as a relational construct and as a motivational construct. As a relational construct, work empowerment concerns influences of managerial practices on employee participation. Empowerment occurs when power of the superior is relinquished to subordinates, and with it authority and responsibility. The subordinates experience a sense of ownership and control over their jobs (Wellins, Byham 
and Wilson (1991). Kanter (1977) argues that managers may strengthen or weaken the selfdetermination and efficacy belief of the employees by providing them access to resources, information, support and opportunity. Sullivan (1994) suggests that a working environment encouraging participation, mentoring and training has to be created for joint decision making. In essence, empowerment is similar to the concept of delegation; however, empowerment gives continuous authority in contrast to temporary authority.

When reviewing work empowerment as a motivational construct, it refers to the perception of employees on their power, autonomy and control. Employees feel energized (Thomas and Velthouse, 1990) and a sense of control of their career (Ripley and Ripley, 1992) if they are empowered. In such sense, power sustains self-determination (Deci, Connell and Ryan, 1989), self-worth (Nielson, 1986) and a belief in self-efficacy (Bandura, 1997).

Empowerment is the act of strengthening an individual's beliefs in his/her sense of effectiveness - a process of changing the internal beliefs of people (Conger and Kanungo 1987, 1988) or self efficacy (see Bandura 1986 on social cognitive theory for self efficacy) which may lead to increased motivation, productivity and effectiveness (Umiker 1992, Pfeiffer and Dunlap 1990, Conger and Kanungo 1988). Whetton and Cameron (1984) regard empowerment as the process of motivation through enhancement of self efficacy, the power to produce effects. Therefore, people who have power are more likely to achieve effectiveness.

An empowering environment fosters weakening of one's belief in personal powerlessness by organisational factors (Kanter, 1979, 1983), supervisory style such as training and company policies (McClelland, 1975), reward systems (Bandura, 1977), and job design. Thomas and Velthouse (1990) suggested that, as well as self-efficacy, a sense of impact, meaningfulness and choice are feelings enhanced on successful implementation of empowerment. Vogt and Murrell (1990) maintain that self-efficacy must be realised and internalised by the employees, otherwise efforts by the management to empower employees will not be of use.

Work empowerment is, therefore, multi-dimensional in nature, involving delegation of power by managers and how individuals perceive and internalise such power. Menon (1995) defines empowerment as 'a cognitive state of perceived control, perceived competence and goal internalisation’ (1995 pp.30).

In this research, a multi-dimensional approach towards work empowerment is taken, following Kanter's (1977) four dimensional framework (Access to Opportunity, Information, Resources and Support). The practice of work empowerment has been put forward in different terms by other researchers. Ripley and Ripley's (1992) suggestions on the activities to be undertaken in an organisation are almost identical to what have been put forward by Conger and Kanungo (1988) for providing self-efficacy. The dimensions include providing leadership, training, recognition, resources allocation, customer focus and teamwork; to achieve goal internationalisation of the employees. Vogt and Murrell (1990) provide six dimensions of empowerment, including education, leading, mentoring, providing, structuring, and a matrix of all; Kirkman and Rosen's (1999) study of team empowerment dimensions comprise external team leader behaviour, production/ service responsibilities, team-based human resources policies and social structure (as described by Spreitzer, 1996).

Kanter (1968) and Sheldon (1971) claim that organisational commitment concerns an individual's affective emotion to the group, as well as their involvement (Mowday, Porter 
and Steers, 1982). Some researchers look into the concept of commitment from a cost perspective and regard it as a side bet (Becker 1960), i.e. investment of something that is valuable to the employees such as time, effort and money. To Kanter (1968), commitment to an organisation also relates to the profit from participating, and the cost of leaving the organisation, such as loss of prestige and stability of a working environment. On the other hand, Marsh and Mannari (1977) focus on the moral responsibility one attaches to the organisation as a result of commitment.

Meyer and Allen (1991) categorise organisational commitment into three components: affective, continuance, and normative but normative commitment is not well supported as a form of organisational commitment (Morrow, 1993).

Affective commitment involves the employee's emotional attachment, identification with and involvement in the organisation, similar to Mowday, Porter and Steer's (1982) definition of attitudinal commitment. Continuance commitment involves the employee's costs associated with leaving the organisation, similar to behavioural commitment. Normative commitment is associated with the employee's feelings of obligation to stay in the organisation. Employees who experience affective commitment stay in the organisation because they want to stay; those influenced by continuance commitment stay because they need to stay and those influenced by normative commitment feel they ought to stay.

Mowday et al (1982) believe that there is a cyclical relationship between affective and continuance commitment, with one reinforcing the other. However, others believe that they are independent factors, such that employees who are bound to an organisation may not be highly committed to the organisation attitudinally, and vice versa. Organisational commitment also depends on the perception of employees (Eisenberger, Huntington, Hutchison and Sowa, 1986). Steers (1997) shows that if the employee finds the organisation to be more supportive, a higher level of organisational commitment will result.

Allen and Meyer (1990) examine the antecedents of different types of commitment, establishing positive relationships with: job challenge, role clarity, goal clarity, goal difficulty, management receptiveness, peer cohesion, organisation dependability, equity, personal importance, feedback, participation, skills, education, relocate, self-investment, pension, community, alternatives, and commitment norm. These 19 variables fall into the labels of work empowerment; opportunity, information, support and resources.

Commitment reflects the relative strength of an individual's identification with and involvement in that organisation (Steers, 1997). Many studies show that high commitment is beneficial to the organisation, although low commitment can be a source of individual creativity and innovation that may be beneficial for the organisation. High commitment facilitates loyalty so a stable workforce can be sustained despite external environment changes. However, high commitment may limit opportunities for mobility, suppressing creativity and innovation (Suliman and Iles, 1999). Generally, previous findings have shown that organisations benefit from a committed workforce because committed employees tend to be absent less often, to make positive contributions and to stay with the organisation (e.g. DeCotiis and Summers, 1987; Beck and Wilson, 2000; Bishop and Scott, 2000).

Hence, it is postulated that work empowerment is an antecedent of commitment, i.e., the individual's perceived extent of work empowerment may increase/decrease the sense of organisational commitment. Such changes in commitment may ultimately affect 
organisational performance, hence, an understanding of the relationship between work empowerment and commitment is desirable.

\section{Research Design}

This paper reports a study of perceived work empowerment and organisational commitment of quantity surveyors (QS) employed in different types of organisations. The case study approach is adopted where four organisations are selected from QS consultancy firms, construction firms, government department (Architectural Services Department) and real estate developers --- these being the major types of organization employing QS in Hong Kong (Rowlinson and Walker 1994). The organisations are selected on the basis that (1) they have the most number of QS employees in their type of organisation and (2) they are willing to participate.

The number of QS employed in the four organisations are 110 in the QS consultancy, 60 in the construction company, 110 in the government department, and 70 in the real estate developer; giving a total of 350 respondents in the sample.

Two sets of questionnaires, based on previous literature, are used. The first set is used to collect information on the perception of the respondents on their job-related empowerment. The empowerment questionnaire was first developed by Chandler (1986) to measure the work empowerment of the nursing profession in Canada. Further improvements on the constructs have been made by the Western Ontario University Research Programme. An acceptable reliability has been established ranging from 0.66 to 0.92 across different studies (Laschinger and Shamian, 1994; Wilson and Laschinger, 1994).

A five-point Likert scale is used ranging from 1 to 5 (from low to high perception of work empowerment). Some items are added to the questionnaire according to Spreitzer's (1995) measurement of information as a dimension of empowerment. The new questionnaire has a total of 33 items under four guiding questions: (1) how much of each kind of opportunity do you have in your present job (8 items); (2) how much access to information do you have in your present job (8 items); (3) how much access to support do you have in your present job (7 items); (4) how much access to resources do you have in your present job (10 items). The alpha coefficients for the four groups of guiding questions range from 0.80 to 0.93 .

The second set is used to obtain information on their perception of organisational commitment. The commitment questionnaire originated from Allen and Meyer's (1990) scale of measurement of organisational commitment - which is regarded as a multi-dimensional construct. After gradual development and improvement after various tests for statistical significance (Meyer and Allen, 1991), the questionnaire adopted for this research is the latest version of Allen and Meyer (2000). The 5-point scale is labelled from Strongly Disagree (1), Disagree (2), Neutral (3), Agree (4) to Strongly Agree (5).

Demographic information on age, tenure, work experience (rank), education level, gender, nationality, and professional qualification status is also collected. 


\section{Results}

There are 152 returned questionnaires from a total of 350 in the sample of four selected organisations, giving a response rate of $43.4 \%$. Valid number of responses is 136 .

To eliminate the problem of multicollinearity, the variables of age, rank and education are dropped in the multiple regression model in order to give a more statistically significant result. The results of the regression analysis are summarised in Table 1.

\section{$<$ INSERT Table $1>$}

The value of the adjusted R-squared is $12.1 \%$ in regression 1 , which means that organisational commitment can be partially explained by the antecedents included. As an antecedent, work empowerment is attributable to organisational commitment with the coefficient of 0.267 and the t-statistic is large (3.052) and significant $(p<0.05)$, i.e., when the perception of work empowerment increases, organisational commitment increases accordingly. The other statistically significant variable at $\mathrm{p}<0.05$ is the consultancy dummy with a negative coefficient of -0.303 . That means the QS consultancy firm has a lower organisational commitment as compared to other organisations in the study.

Further regression equations test the two dimensions of organisational commitment, i.e. affective commitment and continuance commitment. In regression 2, work empowerment is found to be significantly related to affective commitment with a coefficient of 0.488 at $\mathrm{p}<0.05$ (t statistics $=6.215$; adjusted R-squared $=0.293$ ). At one-unit increase of work empowerment, there is an increase of 0.488 in affective commitment.

In regression 3, the adjusted R-squared figure of $8.8 \%$ for continuance commitment, with tstatistics of -1.301 and $p=0.196$, is the lowest among the three regression models and shows no significant relationship between work empowerment and continuance commitment. However, the consultancy dummy is statistically significant $(\mathrm{p}=0.003)$ with t-statistics at 3.024, i.e., the QS consultancy firm has the lowest level of continuance commitment comparing with other organisations, meaning their cost of leaving is lowest in the sample.

Generally, no demographic variables significantly affect commitment - apart from the QS consultancy dummy which is negatively related to continuance commitment (which, subsequently, having a significant effect on organisational commitment). Tenure and Gender are negatively related to organisational commitment but such findings are not statistically significant at 5\%. The negative relationships imply that the male surveyors have lower commitment than the females and that the longer one works in the organisation, the lower one's commitment becomes. The negative sign of tenure does not support the findings of Mathieu and Sajac (1990) and Cohen (1993).

Furthermore, Professional Qualification and Nationality are positively, but not significantly, related to organisational commitment - meaning that qualified Chinese surveyors show higher commitment. 
Since the QS consultancy environment is the only demographic variable which significantly affects organizational commitment, the work empowerment condition of the QS consultancy firm is analysed and compared with the other three organsiations. It is found that the QS firm has the lowest score in access to information amongst the four types of organizations and this may cause a sense of powerlessness and de-motivation. However, it is noted that there is no significant difference in the scores of access to information amongst the four organizations. The QS firm scores second highest in the other components of work empowerment, i.e. access to opportunities, access to resources and access to support. There is no explanation from this study of the negative organizational commitment in QS firms - such would be the subject of further research.

\section{Discussion}

Generally, the results can be discussed in three main areas.

\section{Perception of Work Empowerment}

Work empowerment is found to be positively related to the overall organisational commitment and one of its dimensions, affective commitment, at statistical significance of $5 \%$. It means, generally, the more access of the QS to opportunities, information, resources and support, the more they are committed to their organisations. Such results support the view of Laschinger (1996), Matheiu \& Sajac (1990), and Tao et al. (1998). Feeling empowered in the work environment is conducive to the employees having a higher level of commitment towards their organisations.

However, work empowerment is not significantly related (and yields a negative relationship) to continuance commitment, i.e. the cost of leaving the organisation is possibly lower for those QS who feel empowered. This aspect is worth further exploration through a larger sample. The present finding is not significant, but it may mean that the QS employed in the consultancy firms find it easy (perhaps due to other opportunities open to them) to leave the consultancy and join other (types of) firms. For instance, QS have higher cost of leaving the government as civil servants are rewarded with stable income and attractive retirement packages.

In general, the findings support the argument brought forward by Allen \& Meyer (1990) that organisational commitment is not a single construct since the two dimensions (affective and continuance commitment) give different results from the study of their relationships with work empowerment.

\section{Organisation Variables}

The consultancy dummy is statistically significant (of negative relationships) with organisational commitment and continuance commitment, i.e., the QS in consultancy firm have lower organisational and continuance commitment than amongst the other organisations.

Team working is particularly stressed by the consultancy firm in this study. The firm is divided into 6 teams and each specialises in a particular kind of project. Consultancy organizations have a professional organization structure as described by Mintzberg (1983) while the rest belong to the matrix organization as analysed by Rowlinson and Walker (1994). The former relies more on team work and the latter relies heavily on the inter-department 
communication where quantity surveying is only one specialist branch/department of the whole organisation.

QS working in consultancy firms may not have higher remuneration any more. For instance, overtime payment is cut in the consultancy organisation whereas the contractors still offer bonuses and overtime payment. Moreover, the general age groups of the respondents in the consultancy firm are younger and, therefore, may be more willing to change jobs as their cost of leaving is generally lower.

\section{Demographic Variables}

None of the demographic variables included (tenure, professional qualification, gender and nationality) shows statistically significant result in attributing to the organisational commitment, affective and continuance commitment of QS in this exploratory sample. The probable reason is that the sample size is not large enough to give a statistically significant result.

The findings, thus, support the argument by Blackburn and Rosen (1993), Kanter (1977), Kirkman and Rosen(1999), Steers (1977) and Taormina (1999) that demographic variables are not central to organisational commitment.

\section{Limitations}

It is encouraging to see that work empowerment, as suggested by literature, is an antecedent of commitment in these organizations. More case studies would be required if this result is to be generalized for the QS employed in the Hong Kong construction industry. Organisational commitment is intended to be investigated on case (organization) basis, so that the data to be gathered over time are available for more in-depth analyses in future.

The explanatory powers of the three multiple regression models (organizational commitment, affective commitment and continuance commitment) vary from $9 \%$ to $29 \%$, which means that work empowerment is, but not a very strong, predictor of commitment. There are two possible reasons identified: firstly, the model constructed is not comprehensive enough to incorporate all possible antecedents of commitment, where the major focus of the authors is on the impact of work empowerment on organisational commitment. Secondly, this study is exploratory and the sample is not large enough. Though the perceptions of individuals vary in different situations, the adjusted $\mathrm{R}^{2}$ of the study give similar results compared to some previous studies. The 136 responses are made up of 64 (QS consultancy), 43 (contractor), 24 (government) and 5 (developer). The disappointingly low response from the developer cannot provide a significant discussion on the differences in commitment and empowerment amongst the organizations.

For example, in the study of Taormina (1999) on the effects of socialisation and demographics, the adjusted $\mathrm{R}^{2}$ figures range from $4 \%$ to $38 \%$. In Tao et al. (1998)'s study of the effects of demographic variables and organisational climates on organisational commitment, less satisfactory results on affective commitment with $\mathrm{R}^{2}$ (result of adjusted $\mathrm{R}^{2}$ not available) of $18.3 \%$ and on continuance commitment with of $\mathrm{R}^{2}$ of $3.2 \%$ are obtained. 


\section{Conclusion}

Commitment reflects the relative strength of a person's identification with and involvement in that organisation. Work empowerment enhances self efficacy and, through motivation and commitment, leads to increased performance and effectiveness. In this Hong Kong study, it is found that when the perception of work empowerment increases, organisational commitment increases accordingly. Of the two dimensions (affective and continuance) of organisational commitment, further analysis shows that work empowerment is related to affective commitment rather than continuance commitment. Professional qualification and nationality are positively correlated with both dimensions of organisational commitment, i.e., Chinese chartered QS show more commitment to their organisations.

Generally, in Hong Kong, male QS shows less continuance commitment and the longer the QS has worked for the organisation (tenure), the less continuance commitment one has; and such findings are more so for the QS working in consultancy firms.

The present regression analysis provides a basis to support the relationship of commitment and work empowerment, but more case studies should be conducted to validate the findings for the Hong Kong QS in general. Further model development is also required to take account of other possible antecedents of effectiveness. It is suggested that a detailed conceptual model of work empowerment - motivation - commitment - effectiveness be tested by means of structural equations modelling based on larger scale data collection.

\section{References}

Allen N.J., Meyer J.P. (1990). "The measurement and antecedents of affective, continuance and Normative Commitment to the organisation”, Journal of Occupational Psychology, 63 (1), 1-18.

Allen, N.J., J.P. Meyer. (2000), Construct Validation in Organizational Behavior Research: The Case of Organizational Commitment. In R.D. Goffin, and E. Helmes (ed.). Problems and Solutions in Human Assessment: Honoring Douglas N. Jackson at Seventy. Norwell, Massachusetts: Kluwer Academic Publishers. 285-314.

Arslan, M. (2001) A cross-cultural comparison of achievement and power orientation as leadership dimensions in three European countries: Britain, Ireland and Turkey, Business Ethics: A European Review, 10 (4), October, 340-435.

Antoni C. (2005), Management by objectives - an effective tool for teamwork? International journal of human resource management. 16, 2, 174-184

Bandura A. (1986) Social foundations of thought and action: a social cognitive theory, Englewood Cliffs, NJ: Prentice Hall.

Bandura, A. (1997). Self-efficacy : the exercise of control. New York: W.H. Freeman

Barnes, B. (1986) On Authority and its relationship to power, In Power, action and belief, (Sociological review monograph; 32), London: Routledge \& Kegan Paul.

Bass, B. M. (1960) Leadership psychology and organizational behaviour, New York: Harper.

Beck K., Wilson C. (2000) Development of affective organizational commitment: a crosssequential examination of change with tenure. Journal of Vocational Behavior. 56, 11436

Becker, H.S. (1960). “Notes on the concept of commitment”, American Journal of Sociology, 66 (1), pp.32-40. 
Bishop J.W., Scott K.D. (2000), An examination of organizational and team commitment in a self-directed team environment. Journal of Applied Psychology. 85, 439-50

Block P. (1987), The empowered manager. San Francisco: Jossey Bass.

Chandler, G.E. (1986). The Relationship of Nursing work environments to Empowerment and Powerlessness. Unpublished doctoral dissertation. Utah: University of Utah.

Child J. (1984). Organization : a guide to problems and practice. London: Harper and Row.

Cohen, A. (1993). "Age and tenure in relation to Organisational Commitment. A metaanalysis”, Basic and Applied Social Psychology. 14 (2), 143-159.

Cohen, S.G., Ledford, G.E., Jr., Spreitzer, G.M. (1996). “A predictive model of selfmanaging work team effectiveness”, Human Relations, 49 (5), 643-676.

Conger J.A. (1989), Leadership: the art of empowering others. Academy of Management Executive, (3) 1, 17-24

Conger J.A., Kanungo R.N. (1988). "The empowerment process: Integrating theory and practice”, Academy of Management Review, 13 (3), 471-482.

Conger, J. A., Kanungo, R. N. (1987) Toward a behavioral theory of charismatic leadership in organizational settings, Academy of Management Review, 12, 637-47.

Cordery, J. L., Mueller, W.S., Smith, L.M. (1991). “Attitudinal and behavioural effects of autonomous group working: A longitudinal field study”, Academy of Management Journal, 34 (2), 464-476.

Dainty A., Bryman A., Price A., Greasley K., Soetanto R., King N. (2005), Project affinity: the role of emotional attachment in construction projects. Construction Management and Economics. 23, (3), 242-244

Deci, E.L., Connell, J.P., Ryan, R.M. (1989). "self-determination in a work organization”, Journal of Applied Psychology, 74 (4), 580-590.

DeCotiis, T.A., Summers, T.P. (1987). "A path analysis of a model of the antecedents and consequences of organizational commitment”, Human Relations, 40, 445-70.

Eisenberger, R., Huntington, R., Hutchison, S; Sowa, D (1986), "Perceived organizational support”, Journal of Applied Psychology, 71 (3), 500-507.

French, J. R. P., Raven, B. (1959) The Bases of Social Power, In Cartwright, D. (Ed,), Studies in Social Power, Ann Arbour: Institute for Social Research, University of Michigan.

Giddens, A. (1979). Central Problems in Social Theory: Action, Structure and Contradiction in Social Analysis. Berkeley and Los Angeles: University of California Press.

Giddens, A. (1984) The Constitution of Society, Cambridge: Polity Press.

Hersey, P., Blanchard, K. H., Johnson, D. E. (1996) Management of organizational behavior: utilizing human resources, Upper Saddle River, NJ.: Prentice Hall.

Kanter R.M. (1979), Power failure in management circuits. Harvard Business Review. July/Aug., 65-75

Kanter, R.M. (1968). "Commitment and social organisation: A study of commitment mechanisms in utopian communities”, American Sociological Review, 33 (4), 499-517.

Kanter, R.M. (1977). Men and Women of the Corporation, Basic Books, New York, NY.

Kanter, R.M. (1983). The Change Masters. New York: Basic Books

Kirkman B.L. and Rosen B. (1999). "Beyond self-management: antecedents and consequences of team empowerment,” Academy of Management Journal, 42 (1), 58-74.

Laschinger, H.K. Shamian J. (1994). "Staff nurses' and nurse managers' perception of jobrelated empowerment and managerial self-efficacy”, Journal of Nursing Administration, 24 (10), 30-35.

Leung M.R, Chong A., Ng T., Cheung M.C.K., (2004), Demystifying stakeholders’ commitmnet and its impacts on construction projects. Construction Management and Economics. 22, (7), 701-715 
Likert, R. (1961). “The principle of supportive relationships,” in Shafritz J. M and Whitbeck P. H (ed.) Classics of Organization Theory, Illinois: Moore Publishing Company, pp. 150-160.

Liu A.M.M., Fang Z. (2006), A power-based leadership approach to project management. Construction Management and Economics. 24 (5), 497-508

Liu A.M.M., Walker A. (1998), Evaluation of Project Outcomes. Construction Management and Economics. 16, 2, 209-219

Locke, E.A. and Scheweiger, D.M., Lathan, G.P. (1986). "Participation in decision making: when should it be used?”, Organizational Dynamics, 14 (4), 65-79.

Marsh, R.M., Mannari, H. (1977). "Organisational Commitment and Turnover: A predictive study”, Administrative Science Quarterly, 22 (1), 57-75.

Mathieu, J.E. and Sajac, D.A.(1990). “A review and meta-analysis of antecedents, correlates, and consequences of organizational commitment”, Psychological Bulletin, 108(2),171194.

McClelland, D.C. (1975). Power: The Inner Experience. New York: Irvington Press.

Menon, S.T. (1995). Employee Empowerment: Definition, Measurement and Construct Validation. Vancouver: McGill University.

Meyer, J.P. and Allen N.J. (1991). "A three-component conceptualisation of Organisational Commitment”, Human Resource Management Review. 1 (1), 61-89.

Morrow, P. C. (1993). The Theory and Measurement of Work Commitment. Greenwich, Connecticut: Jai Press Inc.

Mowday, R.T, Porter, L.W., Steers, R.M. (1982). Employee-organization Linkages. New York: Academic Press.

Nielson, E. (1986). "Empowerment strategies: Balancing authority and responsibility", in Srivastra (ed.) Executive Power. San Francisco: Jossey-Bass.

Peansupap V., Walker D.H.T. (2006), Information communication technology (ICT) implementation constraints: a construction industry perspective. Engineering, Construction and Architectural Management. 13, (4), 364-379

Perrow, C. (1973). “The short and glorious history of organizational theory”, in Shafritz J. M and Whitbeck P. H (ed.) Classics of Organization Theory, Illinois: Moore Publishing Company, pp.313-323.

Pettigrew, A. M. (1973) The Politics of Organisational Decision-Making, London: Tavistock Institute.

Pfeiffer I.L., Dunlap J.B. (1990), Increasing productivity through empowerment. Supervisory Management, 35, 1, 11-12

Ripley, R.E., Ripley, M.J. (1992). "Empowerment, the cornerstone of quality: Empowering management in innovative organisations in the 1990s”, Management Decision, 30 (4), 20-43.

Rowlinson, S. M., Walker, A. (1994). The Construction Industry in Hong Kong. Hong Kong: Hong Kong University Press.

Sabiston, J.A., Laschinger, H.K.S. (1995). "Staff Nurse Work Empowerment and Perceived Autonomy”, Journal of Nursing Administration, 25 (9), 42-50.

Sarantinos V., S.T. \& Co J.s.c. (2007) Flexibility in the workplace: what happens to commitment? Journal of Business and Public Affairs. 1, 2, 10 pages (http://www.scientificjournals.org/journals2007/articles/1159.pdf)

Schein, E.H. (1980). Organizational Psychology. Englewood Cliffs, New Jersey: Prentice Hall.

Sewell, W.H. Jr. (1998). “A theory of structure: Duality, agency and transformation”, American Journal of Sociology, 98 (1), 1-29. 
Sheldon, M.E. (1971). "Investments and involvements as mechanisms producing commitment to organisation”, Administrative Science Quarterly, 16 (2), 143-150.

Spreitzer, G.M. (1995). "Psychological empowerment in the workplace: Dimensions, measurement, and validation”, Academy of Management Journal, 38 (5), 1442-1465.

Spreitzer, G.M. (1996). "Social structural characteristics of psychological empowerment”, Academy of Management Journal, 39 (2), 483-504.

Steers, R.M. (1977). “Antecedents and outcomes and organizational commitment”, Administrative Science Quarterly, 22 (1), 46-56.

Suliman, A., Iles, P. (1999). "Is continuance commitment beneficial to organizations? Commitment-performance relationship: a new look”, Journal of Managerial Psychology, 15 (5), 407-426.

Sullivan, K.D. (1994). “Empowerment and control: a New management paradigm”, Educational Leadership, Washington: Seattle University.

Tao, M. Takagi, H, Ishida, M. and Masuda, K. (1998). “A study of antecedents of organizational commitment”, Japanese Psychological Research, 4 (4), 198-205.

Thomas, K.W., Velthouse, B.A. (1990). "Cognitive elements of empowerment: an 'interpretative' model of intrinsic task motivation,” Academy of Management Review, 15 (4), 666-681.

Umiker W. (1992), Empowerment: the latest motivational strategy. Health Care Supervisor,

11, 2, 11-16.

Vogt, J., Murrell, K. (1990), Empowerment in Organizations, San Diego: Pfeiffer and Company.

Vroom V. H. (1964). Motivation - A point of view. In Porter L. W. and Bigley G. A. (ed.) Work and Motivation . Human Relations, Cambridge: Cambridge University Press. pp.8-23

Vroom V.H. (1995), Work and motivation. San Francisco : Jossey-Bass Publishers

Walker, A., Newcombe, R. (2000) The positive use of power on a major construction project.

Construction management and Economics, 18 , 1, 37-44.

Wellins, R.C., Byham, W.C., Wilson, J.C. (1991). Empowered Teams, San Francisco: JosseyBass Publishers.

Whetton D.A., Cameron K.S. (1984), Developing management skills. Glenview, IL: Scott, Foresman.

Wilson B. and Laschinger H.K. (1994). "Staff nurse perception of job empowerment and Organisational Commitment: a test of Kanter's theory of structural power in organisations”, Journal of Nursing Administration. 24 (4), 39-47.

Yukl, G., Falbe, C. M. (1991) The importance of different power sources in downward and lateral relations, Journal of Applied Psychology, 76, 416-423 
Table 1 Regression Results on Organisational Commitment

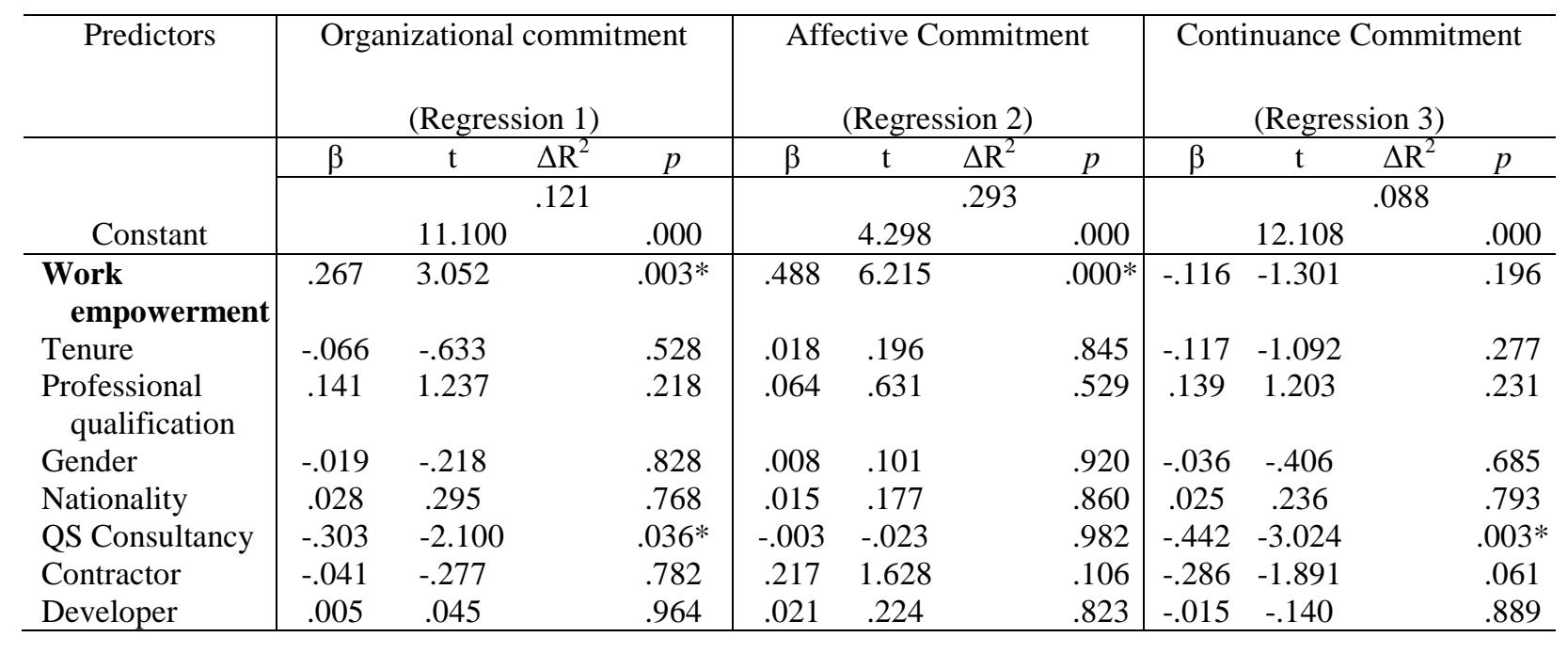

